\title{
HENRY RIDER HAGGARD AND THE HERMENEUTICS OF SUSPICION IN AN AGE OF CONFUSION ${ }^{1}$
}

\author{
M. Önder GÖNCÜOĞLU
}

\begin{abstract}
'Modernity' dissolved religious tradition and increased spiritual anarchy in thought and action in the late nineteenth century. In this highly scientific age, the emerging theoretical works of Marx, Engels, Darwin, Nietzsche, and Freud on god, race, evolution, class struggle, and the human spirit, unsurprisingly produced the first deliriums of modern man. People in such an environment lost their sense of security and their lives could no longer assure spiritual serenity. As a milestone of the late Nineteenth Century, Nietzsche in The Gay Science obviously proclaimed that God is dead. God remains dead. And we have killed him. Therefore, standing amidst the clash between Victorian romanticism and twentieth-century scepticism, Henry Rider Haggard seems to have been affected by the confusions of his era. Therefore, the primary goal of this article is to clarify in what ways the British Africanist H. R. Haggard was affected by the winds of change occurred in his time (1856-1925) and how he represented the discourse of "the hermeneutics of suspicion" in his works.
\end{abstract}

Keywords: Age of Confusion, the Hermeneutics of Suspicion, Science, Religion, God, Victorian England, H. R. Haggard

\footnotetext{
${ }^{1}$ This article is reproduced - but is revisited using a new critical terminology - from the author's dissertation.

${ }^{2}$ Assist. Prof. Dr., Muğla Sttkı Koçman University, Faculty of Letters, Department of Western Languages and Literatures, goncuoglu@mu.edu.tr -nafonder(at)yahoo.com
} 


\title{
KARMAŞA ÇAĞINDA HENRY RIDER HAGGARD VE ŞÜPHE HERMENÖTiĞi
}

\begin{abstract}
ÖZET
Modernite özellikle on dokuzuncu yüzyılın sonlarına doğru dini itikatları da etkileyerek düşünce hareketlerinde tinsel bir karmaşanın yaşanmasına neden olmuştur. Bilimselliğin yükseldiği bu yüzyılda Marx, Engels, Darwin, Nietzsche ve Freud'un tanr1, 1rk, evrim, sınıf mücadelesi ve tinsellik üzerine ortaya koydukları kuramsal saptamalar 'modern insana ait' ilk hezeyanları da üretmiştir. On dokuzuncu yüzyılın kilometre taşlarından Nietzsche The Gay Science adlı eserinde tanrının öldüğ̈nü ve onu öldürenin insanoğlu olduğunu duyurmuştu. Bu bağlamda, yirminci yüzyıl septisizmi ile Viktorya dönemi Romantisizmi arasında sıkışmış, H. R. Haggard da eserlerinde bu dönem karmaşasını yansıtmıştır. Bu çerçevede, bu makalenin amacı İngiliz yazar H. R. Haggard'ın yaşadığı dönemde (1856-1925) cereyan eden büyük değişim rüzgârlarından ne ölçüde etkilendiğini ve 'şüphe hermenötiği' söylemini eserlerinde nasıl yansıttığını göstermek olacaktır.
\end{abstract}

Anahtar Kelimeler: Karmaşa Çağı, Şüphe Hermenötiği, Bilim, Din, Tanrı, Viktorya İngilteresi, H. R. Haggard

Göncüoğlu, M. Önder."Henry Rider Haggard and The Hermenutics of Suspicion in an age of Confusion". idil 5.21 (2016): 277-296.

Göncüoğlu, M. Ö. (2016). Core Topics of Visual Culture Studies and Utilizing Semiotics Method. idil, 5 (21), s.277-296. 


\section{INTRODUCTION}

During the nineteenth century, some of the greatest and, for many, most shocking discoveries and advances in natural science were made. Related to the advances in natural science, philosophers began to radically question established truths, assumptions, and ideologies in which the British had lived by and in for centuries. Along with Darwin's shocking theories, philosophers such as Nietzsche posed very frightening challenges to almost everything 'man' had hung onto. For the first time, God's existence came into question in an organized and systematic way, and for one of the first times, atheists, spiritualists, occultists, and anarchists gathered and publically spoke and wrote, whereas many of the people with such beliefs had been persecuted only a century earlier. Paul Ricoeur's theory concerning the confusion of the late nineteenth century very well exemplifies the situation since in his highly influential work, Freud and Philosophy, he draws attention to three key intellectual figures of the century who, in their different ways, sought to unmask, demystify, and expose the real from the apparent: "Three masters, seemingly mutually exclusive, dominate the school of suspicion: Marx, Nietzsche, and Freud" (Ricoeur, 1970: 32). According to Ricoeur, it was a period in which many sacred, assumed, and naive truths were 'demythologized' and for the first time there was a dominantly growing philosophical and theological discourse rejecting 'Creation', and a more minority voice that began rejecting god. It is for this reason that Ricoeur labelled the discourse of the late 1800s as "the hermeneutics of suspicion" (Ricoeur, 1970: 32).

Victorian England was basically a religious country. The Bible and religious stories were frequently read by people of every class. Yet towards the end of Queen Victoria's reign, the hold by organized religion upon the English people began to slacken because of both a social alienation under the rigid industrial mechanization and the emerging new theoretical insights.

It is a universally acknowledged truth that the human mind always responds to new ideas by finding explanations for the things going on in a people's overall experience. Therefore, the physical expansion of English civilization and the increase in power went along with the loss of spirituality. For the sake of a better understanding of how things worked, the need now for an almighty god was abolished. In the Victorian age, science seemed to develop while the spiritual life seemed to fade away. Through the contributions of new scientific breakthroughs, the Christian understanding of existence was undermined more strongly since the Renaissance. As Rojek states in his Ways of Escape: scientism, "the belief that science is the guide to all reasoning and will provide answers to all questions that can reasonably be asked" (Rojek, 1993: 107) apparently was corrupting the reality of 
supernatural forces. This new sense of apprehension of human existence stood in direct opposition to the belief in a divine will and the static model of existence. In that respect, world order was no longer based on god but on rational principles.

Worshipping and glorifying a god had already been replaced with a worshipping of science. Society at large, however, being still confused about the creation myth was shattered by scientific theory after the Enlightenment period, which ushered in a new sort of Renaissance. Scholars of scientific theorising, and those who followed them, seemed to be worshipping science as a new form of religion. To those who opposed them, scientists seemed to be positing cruel humanistic views and to be lost in a vast scientific materialism leading to arrogance and fascism. A typical example of the new way of thinking is Langwith's clarification on how human society was formed; mind and spirit were separated, he suggested, through a Cartesian understanding of

[t]he idea of human society going through a series of 'stages'. [This] was a keynote [concept] of nineteenth century anthropology. The three-tiered structure was most often employed, and is common to the work of Tylor, Frazer, and Freud. The first tier is the animistic or mythological stage, the second is the religious, and the third is the scientific. The primitive stage of animism was understood to be grounded in the idea of the immanence of 'spirit' in the natural world. (Langwith, 2006: 21)

An outstanding factor that greatly influenced the condition of the mind was no doubt the Darwinian Revolution that was about to take shape. Darwin's idea of nature was very different from that of Isaac Newton and the other thinkers of the eighteenthcentury Enlightenment. It was not the orderly work of the 'Creator'. It was also not the heroic, authentic Nature that the romantics admired. Instead, it was an eternal struggle for survival; that is, 'Red in tooth and claw.' After his famous voyage on the Beagle, Charles Darwin argued that biological life was not created in a single act by god some thousand years ago, but that "it has evolved in a struggle for survival during millions of years" (Burgess, 1974: 180). Therefore, such a new way of thought presented a challenge of the new science to the Judeo-Christian faith. In other words, Darwin's "Theory of Evolution" hit at the "Book of Genesis". In his Origin of Species, which was first published in 1858, Darwin stated that man had evolved from lower forms of life and in the same book he traced the origins of humankind and apes back to one common ancestor. Darwin, hence, became the best-known scientist of his age and occupied a central place in the controversy between science and religion. Moreover, by theorizing that man evolved from lower species, Darwin explicitly rejected the notion that humans were singularly created. In rejecting Creationism, Darwin also meant to reject all notions that humans functioned by the guidance of some transcendent moral codes. Instead, he argued that man's sense of morality had 
been socially constructed over centuries of the human as a social and instinctual animal. He suggested that humanity was part of the natural world. If man is descended from lower animals, what part of that animal remained? Alfred Lord Tennyson suggested:

Can it be that Man

Who trusted God was love indeed,

And love creation's final law --

Tho' Nature, red in tooth and claw

With ravine, shrieked against his creed --

Simply dies the death of all animals?

$\mathrm{O}$ life as futile, then, as frail ....

What hope of answer, or redress?

Behind the veil, behind the veil. (Tennyson, 1849: Canto 56)

This poem was published in 1849 and much before Charles Darwin made his theory public in 1858-9. However, the phrase "Nature, red in tooth and claw" in Canto 56 quickly was adopted by many as a phrase that evoked the process of natural selection. Neuner's following citation presents us the turmoil caused after the publication of Darwin's Origin of Species: After the Copernican Revolution, Darwin's Theory of Evolution "was another de-centring of humankind. The belief in the uniqueness and sameness of God had to cede ground several times, however, before this blow proved fatal" (Neuner, 1997: 51). On this account, the direct connection with god was questioned, the uniqueness and superiority of the white race doubted. Then, only three years after Darwin's ideas were publicized, that is in 1861, a cartoon by Sir John Tenniel in "Punch" depicting the papal opposition to modern civilization was not surprising at all and was thoroughly thought-provoking:

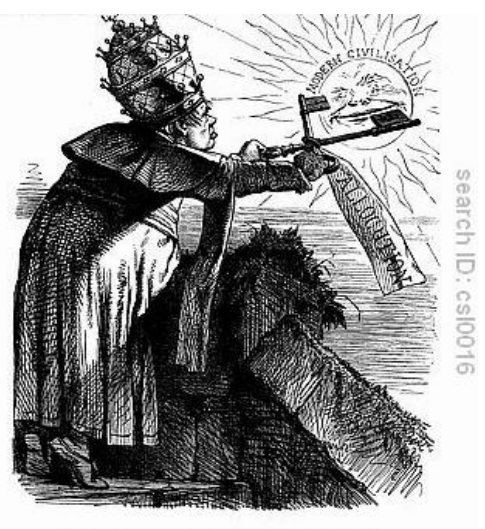

Papal Allocution,-Snuffing out Modern Civilisation. 
(Illustration 1. Tenniel, 1861, “Punch”)

Moreover, Freud's theory and practice of psychoanalysis (1890) even undermined the myth of innocent childhood. According to Freud, humans have unconscious longings that must be analyzed in order to understand human neurotic behaviour. Such unconscious desires are usually sexual and aggressive tendencies. With the help of psychoanalysis, he thought that the source and elements of these impulses could be uncovered. In other words, he theorized that personality is developed by the person's childhood experiences. Therefore, everything which seemed secure and eternal not even a generation ago at the heyday of Queen Victoria's reign had proven fragile and unstable. In a sense, it would not be wrong to state that the manifold effects of what is called modernity today were established implying the first fracture in human history. According to Baker the sudden and swift change experienced through the age is as follows:

On the one hand, there was, for example, the inherited system of the universe. There was God, whose wondrous hand the nightly stars hymned as of old. There was an intricate and reasonably formed universe which He had invented, and everywhere traces of His handiwork could be found. There was the Anglican Church as by law established. There was man, who certainly had a body, and who it was presumed, as even Shelley admitted, to have a spirit and probably a soul. There were the Queen, God bless her, and England's wooden walls, and the Duke of Wellington. In fact, there was a noble world inhabited by noble beings. And there came crashing down on the Victorian a bewildering variety of changes, discoveries, and revolutions. (Baker, 1950: 22)

As a result of all the material changes and the side-effect of alienation under industrialization, a spiritual void permeated the society. Scientific materialism did not seem to be appropriate replacement.Therefore, in the Victorian era a great number of people's lives were increasingly marked by a sense of insecurity, with no one ever really knowing how or where to take shelter. It is for this reason that to preserve the old sense of security became a practical solution. In terms of literary aspects, there were, of course, several movements out of which reactions merged against eighteenthcentury rationalism and physical materialism. In this respect, it is not surprising to see the revival of the Gothic and of Romanticism as the movements to counter the threatening impact of newly started industrial order in this age.

\section{Henry Rider Haggard's Place in the Hermeneutics of Suspicion}

The British Africanist author Henry Rider Haggard (1856) as a child of this confusing age can be said to have been affected to a large extent by the swift change occurred in the age. H. R. Haggard has fifty-eight volumes of works and seven 
volumes of political, economic, and social history, including adventure romances, historical novels, short stories, an autobiography, and several reports concerning the mishaps of urban life. Being not content with the answer of 'God', he wrote on a wide range of topics such as, tribalism, occultism, spiritualism, mysticism, and romanticism and reincarnation. The most definite characteristic of his works is that they deal mostly with the clash of the morals lost under the new scientific world order of his time. Amplified by the discoveries made, and the theories for the first time introduced in this age, his doubts about a unilateral westernized understanding of the creation myth's impact, can be said to have affected Haggard's inner questions.

Both the evolutionary theories of the age, the travels he made to faraway, alien lands, and his first-hand encounters with different cultures in various parts of the world, influenced Haggard spiritually to a large extent and provided him a lure for his imaginative spheres. It is for this reason that his concern in his romances varied to a large extent: such as his concern for man's spiritual being, the influence of evil, the dangers of a materialistic society, man's need any kind of religion, the importance of nature, reconciling man and the cosmos, belief in reincarnation, the importance of love, and the situation of women -- all of which were carved very skilfully in his romances. The full palate of all of these concerns functionally directed his strategic search for a greater understanding of man in the universe. When he focused his exceptional imaginative ability and thinking on all of these concerns, his romances grew more and more amplified.

As early as his childhood years, he seems to have been intuitively formed toward spiritual insights. As a result of this early spiritual development, it is reasonable to suggest that his romances created in adulthood deal, at times implicitly and at times explicitly, with the concepts of African primitivism vis-a-vis British civilisation, a Christian God vis-a-vis African mysticism, Abrahamic religions vis-avis animism, Zulu tribalism and occultism vis-a-vis a Cartesian understanding of the nature, and also the concept universality.

It was from his mother that Haggard undoubtedly drew his literary talents. She wrote poems and songs that were published in several journals. The lines from her Life and Its Author seem to have engraved themselves deeply on her son's imagination, especially where she expressed human bewilderment regarding the purpose of life: "Oh human mind! Entangled in the maze, / Perplexed of these our philosophic days, / Each path of thought thou dost pursue, / Each path rejectunfound the mystic clue. / Then whither fly?... Life infinite, diverse, pervading all... / Dark web involved! Oh mystery profound!" (qtd in Ellis, 1978: 18-19). Likewise, in her poem Myra, or the Rose of the East: A Tale of the Afghan War, written only a year after Haggard's birth, she reflected on the mysterious law or purpose of the universe, 
which, of course, became the vital themes that Haggard would build upon in his fiction:

\author{
Time passes -- silently but swift \\ And down its mighty current drift \\ The circling worlds on high; \\ We gaze upon them till some spark \\ Becoming till now, extinguished dark \\ A blank leaves in the sky; \\ That which our hearts stand still with dread \\ We think, that orb's bright course is sped \\ Our haven may be nigh; \\ An hush our souls in silent awe \\ And muse on thy mysterious law \\ Unknown eternity. (qtd in Ellis, 1978: 17)
}

The poem is undoubtedly a sensed and thought out plea for modesty during the period when science was becoming the new religion and the discoveries of Charles Darwin, encompassing most of the nineteenth century, were being severely debated. In the spirit of this poem, then, one may underscore the observation, more than a mere speculation, that the longings for a spiritual regeneration imbedded in Haggard's works are raised from the similar veins of his mother's unfulfilled searching. Ella Haggard says that science can explain 'how' but not 'why': "Is nature God? Are gases reigning laws? Atoms fortuitous - the Great First Cause?" (Ellis, 1978: 17). It is significant that, like his mother, Haggard also became intrigued with the ideas raised by evolutionary thought so indicative of his time; as it would be equally indicative of his thinking that he chose to preface Allan and the Ice-gods (1927) with a verse from William Herbert Carruth's "Each In His Own Tongue":
A fire mist and a planet,
A crystal and a cell,
A jellyfish and a saurian
And caves where the cave men dwell;
Then a sense of law and beauty,
And a face turned from the clod --
Some call it Evolution,
And others call it God. (Haggard, Alan and the Ice-gods:
Preface)

Haggard's mother Ella Haggard, however, became the primary catalyst for Haggard to formulise his first questions concerning 'god', eternity, and the idea of existence in the world. His introversion in his early childhood years undoubtedly 
widened his spiritual merits and caused him to safeguard a wide variety of memoirs to work on in his romances.

Like his contemporaries facing the impact of Darwin's theories, Haggard must have regarded the cause of creation as one of several possibilities, as Sandison believes (Sandison, 1967: 28); because for Haggard things were in a continuous process. Accordingly, the first possibility was that there was a principle of order in the universe dictated by god. A second possibility was that there was a principle of order in the universe, but its determination was completely mechanical, with a cosmic accident as its first cause. A third one was that there was no order inherent in the universe and chance dominated all. A fourth one was that what order there is in nature has been put there by man. However, as Sandison argues, "If the question of "why' brought little comfort to Haggard, the question of 'how' brought him the breadth of a vision which many contemporary Victorians lacked" (Sandison, 1967: 29). Being a contemporary of his, J. A. Symonds echoes the primary question of the era: "By penetrating our minds with the conviction that all things are in process, that the whole universe is literally 'Becoming', it has rendered it impossible for us to believe that any one creed or set of opinions possesses finality" (Symonds, 1978: 48). Haggard in his Stella Fregelius (1904) likewise touches on the same issue with almost a similar awareness:

It seems to be a law of life that nothing can stand completely still and changeless. All must vary, must progress or retrograde; the very rocks in the bowels of the earth undergo organic alterations, while the eternal hills that cover them increase or are worn away. Much more is this obvious in the case of ephemeral man, of his thoughts, his works and everything wherewith he has to do, he who within the period of a few short years is doomed to appear, wax, wane, and vanish. (Haggard, 1904: 289)

Likewise, in Smith and the Pharaohs (1913), a story serialized in The Strand, the narrator's explanation of science and of scientists and their role in the area of human knowledge sets forth Haggard's uncertainty about their sovereignty. Haggard, overwhelmingly dubious about the notion of a god, is also troubled about the idea of science:

Scientists tell us they know all that there is worth knowing about man, which, of course, includes woman. They trace him from his remotest origins; they show us how his bones changed and his shape modified, also how, under the influence of his needs and passions his intelligence developed from something very humble. They demonstrate conclusively that there is nothing in 
man which the dissecting-table will not explain; that his aspirations towards another life have their root in the fear of death, his affinities with the past are merely inherited from remote ancestors who lived in the past, perhaps a million years ago; and that everything noble about him is but the fruit of expediency or of a veneer of a civilization .... Man, in short, is an animal. Such are the facts, they (or some of them) declare. (qtd in Haining, 1913: 148)

Having uncertainties about both science and religion, Haggard draws the idea of all religious beliefs into question. In his The Yellow God, he puts forth his uncertainty about religious belief. He further calls such belief rubbish through the words of Aylward, the character whose materialist outlook needs shattering:

I am a man who has never believed in anything I cannot see and test, one who utterly lacks faith. In my leisure I have examined into the various religious systems, and found them to be rubbish. I am convinced that we are but highly-developed mammals born by chance, and when our day is done, departing into the bleak nothingness out of which we came. (Haggard, 1912: 78)

Undoubtedly, after Darwin had posited man's branching origin as a homosapien descending from an origin similar to the Ape, science revealed to Haggard the nightmare of man's inhuman origins lurking within human history. He therefore dealt with the idea of god and death widely in his works. In Mahatma and the Hare, he deals with the clash of spirit and flesh very prominently laying bare his obsession with the inevitably of death and his awareness of the vanity of material things:

Occasionally when I am in deep sleep, some part of me seems to
leave my body and to be transported quite outside the world. It
travels as though I were already dead, to the Gates that all who
live must pass, and there takes its stand, on the Great White
Road, watching those who have been called speed by
continually. Blinded by their pomps and vanities, they cannot
see, they will not see it always growing towards the feet of
everyone of them. (Haggard, 1991: 26)

She, however, represents his deep contemplation on the clash of spirit and flesh most clearly, where the beast is revealed in man's essence at the very end of the work. The role and the place of the spirit in a materialist world had been a big problem for his existential uncertainties. It is for this reason that he defined his search in Wisdom's Daughter as such: "In that book is my philosophy ... the Eternal War between Flesh and Spirit, the Eternal Loneliness and Search for Unity" (qtd in Ellis, 1978: 1). On the 
other hand, the implications of science during this age also threatened the ideas of a divine order. The high position of man in the universe was drawn into an uncertainty that, to a large extent, was derived from large changes taking place in science and from the insecurity inherent in the notion of a divine order.

Doubtful about his position in the universe, a sceptical Haggard is therefore seen very frequently in his works. He seems to have questioned and tried to understand different cultures and their different types of creation myths and rituals. In Queen of the Dawn (1925), believing that man finds god in his own heart, Ian remarks on the very same issue: "But what his name may be I cannot tell you. Some call it Justice, some call it Freedom, some call it Hope, some call it Spirit" (Haggard, 1925: 46). Likewise, after his visit to Egypt, his contemplation on the idea of religion seems to have become varied, for he concludes that there are several types of belief systems:

I look upon religion ... as a ladder stretching from earth to heaven -- a Jacob's ladder, if you will, whereby stretching with many slips and backwards fallings, mankind climbs towards the skies. In that ladder the faith of the old Egyptians was a single rung, that which we follow is another rung, and perhaps there are many more, out of our sight and knowledge, for God's skies are faraway. (Ellis, 1978: 251)

His intimate knowledge of, and great respect for Africa's people, inspired his view of religion and, consequently, morality also to a large extent. In his 1887 lecture on the Zulus, Haggard outlined their belief system that seemed to him even more comforting than other celestial systems:

They believe in a God, the Unkulunkulu -- the Almighty, the Greatest Great; he is the Creator, the Source of all Life. The Zulu mind does not indeed venture to define the Deity, or to measure his attributes. To them he is a force, vague, immeasurable, pressing round them as air, and as the air impalpable, and as the air all-present. They believe, too, in guardian spirits who watch over the individual, interposing at times to ward off danger from him. In the same way the nation has a guardian angel, Inkosana-y-Zulu, the Queen of Heaven, who in the form of a young and lovely woman, appears at moments of national importance and makes a communication to some chosen person. She appeared thus just before the Zulu War and her message produced a great effect in the country, but what she said nobody knows. (Lilias Rider, 1951: 54)

Doubtful about the idea of god, Haggard, in fact, deemed all religions to have sprung from the same light as the components of certain different cultures. $\mathrm{He}$ therefore had a peaceful view of different religious beliefs. The only thing he could not take for granted was the confining pressure of religions on their followers. In this 
respect, Catholicism with its seemingly imprisoning aspects, was not the only belief system he criticised. He also took on Islam in his autobiography as follows: "I am not prepared to quarrel with any religion worthy of the name, unless it be that of Mahomet in certain of its aspects. I have learned that they all spring from the same light; through the world being, as it were, cut crystal, that light flows from its facets in different-coloured rays" (Haggard, 1926: 87). Thus, Haggard's comparative observation of other celestial religions in his autobiography reveals his objections to all kinds of dogmas, regardless of the origin that they stem from: "Islam preaches a God" and says, "You may keep your wives, but you must give up spirituous liquor." "Christianity also preaches a God" but says, "You must put away all wives except one, but spirituous liquor is not forbidden" (Haggard, 1926: 38).

The idea of people being shut up in monasteries particularly horrified him; on this very point, he once criticised one of his close friends, Justin Sheil, who was going to be a Trappist monk of the Cistercian Order. On this issue, in his autobiography, Haggard points out:

His [Sheil's] idea was that by shutting himself up in an iron box he would avoid sin and its "hideous consequences." But I wonder now, as I wondered then, whether, supposing the capitulation to the natural impulses of the body to be cardinal sin, such sin is really avoided by the method of the iron box? True, they cannot be gratified, for, if you wish to drink, there is no whisky; if you wish to make love, there is no woman, and so forth. Yet in that case does not the wish assume the proportions of the accomplished deed? (Haggard, 1926: 89)

Haggard wrote a letter to his friend to try to dissuade him from wasting his life in a monastery but it did not work and his friend became a monk after taking his vows as Brother Basil. Basil responded to Haggard in a kind way in his letter and there he also concluded with an interpretation of Haggard's sceptical outlook towards the idea of god:

You go to the originals to discover what Hegel or Comte really teach, as you are eager enough to find out all about Darwinism, etc., but as for Catholics, you not only don't inquire from them what they really teach but you assume to lecture them. Having relieved my mind so far, I can assure you your letter was far from giving me offence; on the contrary; I know very well you are not singular in your views, and that many who call themselves my friends think the same. (Haggard, 1926: 88)

After getting married to Louisa Margitson in 1880, he visited Brother Basil in the monastery and tried one more time to get him to give up monastic life. However, his friend replied: "Many have scolded me and lectured me; you are the first who ever 
came here to try to snatch me from what you believe to be an intolerable fate" (qtd in Ellis, 1978: 76). Observing a large amount of belief systems in many different societies of the world, and contemplating on their functions within societies, Haggard immersed himself in serious thinking about the course and purpose of the universe with the aid of his friend's profound remark on his thinking. Ellis states: "Perhaps it was the start of Rider's serious thinking about the course and purpose of the universe. Brother Basil, he observed, had lived a hard life seeking the truth through his religion, but so had the holy men of Egypt and the Tibetan monks. That which was, still is and shall be while the world endures; not in one religion, but in many" (Ellis, 1978: 76).

As Bursey argues, Haggard was willing to embrace "whatever gods there be" (Bursey, 1972: 26). His curiosity regarding spiritualism and psychical phenomena and his deep belief in reincarnation, accordingly, became the means of his quest for answers. Therefore, in She Haggard indicates his own doubts here since we observe no enduring security attained there. In this context, when Holly tries to teach her doctrines of Christianity, how Ayesha responds is worth mentioning, as it reveals Haggard's quest to find answers to his tormenting questions: "The religions come and the religions pass, and civilisations come and pass, and naught endures but the world and human nature" (Haggard, 1991:161). Some unfamiliar customs and rituals of foreign cultures that he did observe throughout all his life became very influential in his perception of life. His tolerance comprehended, particularly, the great religions of the East.

Haggard was always fascinated by the supernatural. He was much involved in studying reincarnation to explain the mystery of life and death. He became interested in mystical matters and kept a careful eye on physical research. Furthermore, he became a deeply interested student of ancient Egyptian and Teutonic customs and religion: "From a boy ancient Egypt had fascinated me, and I had read everything concerning it on which I could lay hands .... I love the Norse people of the saga and pre-saga times .... I have a respect for Thor and Odin; I venerate Isis, and always feel inclined to bow to the moon!" (Haggard, 1926: 153). Moreover, commenting on ancient theologies, he also remarks that he had been an Egyptian and a Norseman in previous incarnations: "However these things may be, with the old Norse and the old Egyptians I am at home. I can enter into their thoughts and feelings; I can even understand their theologies" (Haggard, 1926: 153). Undoubtedly, this background widened his interest in myth and the patterns of death and rebirth, which became very prominent in his fiction. As Pocock suggests: "He kept an open mind about spiritualism and reincarnation, having the idea that his knowledge of Ancient Egyptian life must come from firsthand experience in a former existence" (Pocock, 1993: 91). 
It is clear that he felt within himself deep spiritual splits that he could not figure out. As Cohen put it, "As one of the few men on earth gifted with a second sight; he firmly believed that he was supposed to explore the "spiritual never-lands" (Cohen, 1968: 224) and deduce what he could. Although there were some resolutions he reached late in his life, he was, at bottom, a man of doubt throughout his life about "the hidden power of the spiritual" (Cohen, 1968: 224). He engraved this spiritual quest of his for the hidden mysteries in the universe very skilfully in his works. His admission about this in his last speech on November the 24th, 1924, is very interesting:

For it seems to me as I grow old that the spirit of man is like those great icebergs which float in Arctic seas -- towering masses of glittering blue green ice, which yet hide four fifths of their bulk beneath the water. It is the hidden power of the spirit which connects the visible and invincible: which hears the still small voice calling from the infinite. "Reported in The Times, London, November 26, 1924” (qtd in Ellis, 1978: 11)

In his books the reader observes this exceptional view of his, which he attributed to his well-known character Quatermain, for whom he notes in The Treasure of the Lake: "It becomes everyday more clear to me, Allan Quatermain, that each of us is a mystery living in the midst of mysterious, bringing them with us when we are born and taking them away with us when we die; doubtless into a land of other and yet greater mysterious" (Haggard, 1952: 6).

His interest in the mysterious realms of life drove Haggard's particular affinity to Egypt and its ancient beliefs. Intrigued highly by Egyptology, Haggard must have also realized that the Egyptians' Trinity of Osiris, Isis, and their son Horus presented startling parallels to Christian belief. In this regard, he sensed that the solution of a mystery for him must have laid in another. His wondering whether all religions were linked by human need or by metaphysical reality must not have left him in peace. It is for this reason that in The Witch's Head (1884), when Ernest grills Alston about his religious views, he echoes Haggard's scepticism as follows:

Religion? Which religion? There are so many, Our Christian God, Buddha, Mohammed, Brahma, all number their countless millions of worshippers. Each promises a different thing, each commands the equally the intense belief of his worshippers, for with them all blind faith is a condition precedent; and each appears to satisfy their spiritual aspirations. Can all of these be true religions? (Haggard, 1884: 213)

Moreover, in this same work when his two characters, Ernest and Alston, conjecture upon the notion of religion, it seems that they come to the resolution that 
the same spirit underlies all religions. Alston, however, denies the idea of an eternity of either heaven or hell:

I do not deny the Almighty power. I only deny the cruelty that is attributed to Him. It may be that from the accumulated mass of the wrong and bloodshed and agony of this hard world that power is building up some high purpose .... Our tears and blood and agony may produce some solid end that now we cannot guess; their volume, which cannot be wasted, for nothing is wasted, may be building up one of the rocks of God's far-off purpose. But that we should be tortured here for a time in order that we may be indefinitely tortured there [and he pointed to the stars], that I will never believe. (Haggard, 1884: 214)

Furthermore, Haggard's observation of the ancient Egyptian idea of Ka is also noteworthy in this context, as he elucidates this idea as something "invisible, ... that is stronger, purer, more enduring" than man himself. Therefore, what man senses in life as truth is rooted in his own heart, yet transcends his physical form. Most of his works, by this same token, helped him fight against the intense scepticism imbedded in his mind to display his exploration of the idea of god and his search for an alternate universal order. Cohen depicts his probing curiosity as follows:

Although he eventually settled upon a working faith, which included a Christian God and devil, an Egyptian belief in reincarnation, and a concept of love reminiscent of Socrates's definition in the Symposium, Haggard always sought ultimate proof. If in an African adventure he gave the Victorian reading public a 'way out' of their narrow distress, in Ayesha he gave them something more, a symbol of the mystery of their existence. For the story of the goddess-spirit, the quest for the feminine universe, is mankind's quest for truth and understanding. (Cohen, 1968: 224)

However, after the idea of a god was shattered by immense progress in science, Haggard can be said to have opposed the replacement of a divine understanding of the cosmos with a pure scientific explanation since he regarded materialism as an offshoot of science. In his historical novel Pearl Maiden, Haggard, as Katz argues, reveals dramatic polarities through "Miriam, the faithful Catholic, and Caleb, the Jew, who was unable to divine that mind is greater than matter, while spirit is greater than mind" (Katz, 1987: 118). In the end after many disasters, which are seemingly irrevocable, spirituality conquers all. Likewise, in The Ghost Kings, Rachel Dove as the incarnation of the divine Inkosazana is opposed to the perversely materialist Ishmael. Ishmael falls in love with Rachel because "she was beautiful, which appealed to his strong animal nature, and spiritual [one also], which appealed to a materialist soaked Kaffir superstition” (Haggard, 1908: 131). 
Materialism emerging as a persecutor of science seems to have been harshly opposed by Haggard in his works. He frequently dramatizes the conflict of matter and spirit. Furthermore, he persistently attempts to subvert the authority of science and a materialist world view. Having represented Quatermain continually as a pragmatic man, Haggard ironically makes his fall from reason more credible. On the style and significance of Quatermain, Cohen suggests:

Quatermain believes in scientific realism: all unusual phenomena must be proved before he will believe them. This is not a world of cock and bull ghost stories, of fairies and wraiths; this is a man's world, and science is a man's tool for providing or disproving. From the outset Quatermain is a hard-headed cynic who has no use for humbug, will not tolerate magical hocus pocus, and absolutely abhors superstition. He is, in a word, a sceptic, and since he usually is the teller of the tales, he tells them from a sceptical point of view... And then suddenly then, the sceptic comes face to face with the impossible, the imponderable, and his reaction is just what we would expect: he does not believe what he sees. But there it is before him, and he looks for some explanation. He subjects the phenomenon to all the tests of reason: Ayesha is after all there before his own eyes, and her story is air-tight; King Solomon's treasure is not something he imagines: he runs his fingers through the cold, glittering gems. Perhaps, dear reader, the sceptic is forced to suggest, there is more in heaven and earth than is dreamt of in our scientific realism. (Cohen, 1968: 222)

In terms of his overwhelming quest concerning the creation myth, God and the evolution in the universe, one of his last works written in his late years serves as a summary of his inner thoughts. In this work, When the World Shook (1919), he gets three characters to echo all of his own uncertainties. He, to this end, introduces the confused seeker of truth, Arbuthnot, and then his friends Bickley and Bastin, who serve as the representatives of science and religion respectively. Bickley regards life merely as "a short activity bounded by nothingness before and behind" (Haggard, 1919: 24). He, furthermore, sees man as a "brute-descended accident and no more" (Haggard, 1919: 15). Bastin, on the other hand, thinks that life is nothing more than "a conventional golden-harped and haloed immortality, a word of which he did not in the least understand the meaning" (Haggard, 1919: 24). Arbuthnot as the confused seeker of truth, like Haggard himself, echoes Haggard's own question:

$[\mathrm{O}] \mathrm{r}$ was it something quite different from either of these, something vast and splendid beyond the reach of vision, something God-sent, beginning and ending in the Eternal Absolute and at last partaking of His attributes and nature and from aeon to aeon shot through with His light? And how was the truth to be learned? I asked my Eastern friends, and they talked vaguely of long ascetic preparation, of years upon years of learning, from whom I could 
not quite discover. I was sure it could not be from them, because clearly they did not know; they only passed on what they had heard elsewhere, when or how they either could not or would not explain. (Haggard, 1919: 24)

Quite doubtful, both about the progress made through pure science and about a god himself, Haggard, drew the idea of all religious beliefs into question. He, in a sense, anticipated the more recent researches of the South African botanist Lyall Watson (1939-2008) who, like Haggard, contemplated on the same dichotomy of the worlds of religion and of science into, a metaphysics on which the West has divided itself. Watson expresses the very essence of Haggard's lifelong quest to discover material or psychical evidence bridging the worlds of belief and science:

\begin{abstract}
Science became very limited in its focus to mechanical, material things, and religion became very introverted; it became very concerned just with the human spirit and with morality and so forth, and so religion signed over the whole of the natural world including the cosmos to science and science signed over to religion human ethical questions and left this terribly limited domain as the sphere of religion. In most traditional cultures, these are not separated in that way. (Watson, 1987: 11)
\end{abstract}

To sum up, the late nineteenth century observed religious dogma shaken by higher criticism and the advances of science. Darwin's evolutionary theory resulted in anti-religious sentiments, while the poorer parts of the population, particularly in the large cities, had become uninterested through poverty and negligence in religious expression of any sort. Therefore, for particularly the middle class, the transition from Victorian romanticism to fin-de-siècle improvement was by no means a promising success of the new over the old. However, the implications of science during this age threatened the ideas of a divine order. The high position of man in the universe was drawn into an uncertainty that, to a large extent, was derived from large changes taking place in science and from the insecurity inherent in the notion of a divine order. Haggard, therefore, wrestled, more vigorously, with the ideas of creation, existence, god, truth, renovation, and reconciliation with the cosmos in an era when the industrial and scientific revolutions had changed the face of England and the characters of its citizens forever as Bob Dylan's rhyme entitled Idiot Wind expresses the situation: "Now everything's a little upside down. / As a matter of fact the wheels have stopped. / What's good is bad, what's bad is good. / You'll find out when you reach the top, / You're on the bottom. (Dylan, 1974). Haggard was naturally affected by the winds of change. Having great doubts both about science and creationism, he therefore searched for unity in his narratives of primitive lives and he welcomed his readers to witness in his works how he searched to find a universal design. His wrestling with all such concepts like creationism, primitive, civilised, reincarnation, and mysticism gave also his readers the opportunity to see the rethinking of his/her own place in the world. 


\section{References}

Baker, Joseph (ed.), The Reinterpretation of Victorian Literature. Princeton:

Princeton UP, 1950.

Burgess, Anthony. English Literature. Essex, England: Longman, 1974.

Bursey, Wallace. Rider Haggard: A Study in Popular Fiction. Diss. Memorial University of Newfoundland, 1972.

Cohen, Morton. Rider Haggard: His Life and Works. London: Macmillan, 1968.

Dylan, Bob. “The Idiot Wind.” (1974) 4 Oct 2011. Retrieved from

http://www.bobdylan.com/songs/idiot-wind

Ellis, Peter B. H. Rider Haggard: A Voice from the Infinite. London:

Routledge and Kegan Paul, 1978.

Haggard, Henry R. Stella Fregelius. London: Longmans, Green \& Co., 1904.

_- $\quad$ The Ghost Kings. London: Cassell \& Co. Ltd., 1908.

- - The Yellow God. London: Cassell, 1912.

- - When the World Shook. Being an Account of the Great

Adventure of Bastin, Bickley, and Arbuthnot. London: Cassell \& Co. Ltd., 1919.

_- $\quad$ The Witch's Head. London: Hurst \& Blackett, 1924.

_. $\quad$ Queen of the Dawn, a Tale of Old Egypt. London: 
Hutchinson \& Co., 1925.

_- $\quad$ The Days of My Life: An Autobiography. London:

Longmans, Green \& Co.Vol. I \& II, 1926.

_ _. Allan and the Ice Gods. London: Hutchinson \& Co., 1927.

_- $\quad$ The Treasure of the Lake. New York: Doubleday, 1952.

_- $\quad$ She. Oxford and New York: Oxford UP., 1991.

_- $\quad$ The Mahatma and the Hare. London: Longmans, 1991.

Haggard, Lilias R. The Cloak I left: A Biography of the Author Henry Rider

Haggard. K.B.E London: Hodder and Stoughton, 1951.

Haining, Peter (ed.), Smith and the Pharaohs. London: Micaheal Joseph, 1913.

Katz, Wendy. H.Rider Haggard and the Fiction of Empire: A Critical Study of

British Imperial Fiction. Cambridge UP., 1987.

Langwith, Mark J. A Far Green Country: An Analysis of the Presentation

of Nature in Works of Early Mythopoeic Fantasy Fiction. Diss. University of

St. Andrews, 2006.

Neuner, Ralf. “Ways of escape in Rider Haggard's King Solomon’s Mines,

English Literature around 1900”. Englisches Seminar der FU Berlin, Sommer

Semester, (1997): 48-58.

Nietzsche, Friedrich. The Gay Science. Trans. W. Kaufmann. New York: 
Vintage, 1974.

Pocock, Tom. Rider Haggard and the Lost Empire. London: Weidenfeld and Nicolson, 1993.

Ricouer, Paul. Freud and Philosophy: An Essay on Interpretation. Trans.

D. Savage. New Haven: Yale U.P., 1970

Rojek, Chris. Ways of Escape. London: MacMillan Press, 1993.

Sandison, Alan. The Wheel of an Empire: A Study of the Imperial Idea in

Some Late Nineteen and Early-Twentieth-Century Fiction. London: Macmillan, 1967.

Symonds, John A. Essays Speculative and Suggestive. The Journal of

Imperial and Commonwealth History, (18 May 1978): 42-78.

Tennyson, Alfred. In Memoriam. “Canto 56.” (1849) 14 Oct 2009. Retrieved from

http://santitafarella.wordpress.com/2009/10/14/was-alfred-lord-tennysons-

canto-56-in-whichhe-calls-nature-red-in-tooth-and-claw-the-product-of-his-

reading-charles-darwins-the-origin-ofspecies/

Watson, Lyall. Lifetide. London: Sceptre, 1987.

\section{Illustration 1.}

Tenniel, John. "Papal Opposition to Modern Civilisation”, Punch, (1861) 19 Feb 2010.

https://archive.org/stream/punc186100lemouoft\#page/n175/mode/2up 